\title{
Cephradine Monohydrate
}

National Cancer Institute

\section{Source}

National Cancer Institute. Cephradine Monohydrate. NCI Thesaurus. Code C47971.

The monohydrate form of cephradine, a beta-lactam, first-generation cephalosporin

antibiotic with bactericidal activity. Cephradine monohydrate binds to and inactivates penicillin-binding proteins (PBP) located on the inner membrane of the bacterial cell wall. PBPs participate in the terminal stages of assembling the bacterial cell wall, and in reshaping the cell wall during cell division. Inactivation of PBPs interferes with the crosslinkage of peptidog lycan chains necessary for bacterial cell wall strength and rigidity. This results in the weakening of the bacterial cell wall and causes cell lysis. 